\title{
Phillipsova křivka v podmínkách české ekonomiky na trhu práce
}

\author{
Miroslava Pucandlová
}

Vedoucí práce: RNDr. Jitka Bartošová, Ph.D.

\section{1. Úvod}

Při hledání vhodného tématu pro zpracování seminární práce mě zaujal mě článek „Nobelova cena 2006 - Nobelův výbor s cenou za ekonomii zaspal dobu“, který byl publikován v Hospodářských novinách dne 10. 10. 2006.

Autor se v článku vyjadřuje k udělení Nobelovy ceny za ekonomii. Získal ji ekonom Edmund S. Phelps za ,analýzu intertemporálních substitučních vztahů v makroekonomické politice“, který zkoumal, zdali i v makroekonomii platí něco za něco, a to hlavně v čase. Tedy vlastně zjiš oval, zda je možné, aby tvůrci ekonomické politiky dokázali „vyměnit““ úroveň některých veličin, pokud by shledali, že je to výhodné - např́klad zda je možné vyměnit nižší nezaměstnanost za vyšší inflaci.

Tím se autor dostává k Phillipsově křivce a popisuje její vývoj s tím, že Nobelova cena měla být udělena dříve, protože dnes už je ekonomická teorie zase o kus dál.

\section{Porovnání jednotlivých modelů}

\subsection{Původní model Phillipsovy křivky}

Pro výpočet uvedených křivek použiji reálná měsíční data z české ekonomiky za období 1997-2006, která obsahují celkem 120 pozorování. Z dat o inflaci, očekávané inflaci a nezaměstnanosti jsem určila model, vycházející z původní Phillipsovy křivky, který popisuje závislost míry celkové inflace $\pi_{t}$ na nezaměstnanosti $U_{t}$ a na náhodné složce $\varepsilon_{t}$ (viz vztah 1/6). Na základě měsíčních údajů o inflaci a nezaměstnanosti v České republice jsem odhadla Phillipsovu křivku v lineárním tvaru

$$
\hat{\pi}_{t}=17,173-1,619 \cdot U_{t} .
$$

Z odhadnutého vztahu (2/1) lze vyvodit závěr, že míra inflace v ČR v uvedeném období při nulové nezaměstnanosti by činila $17,173 \%$, přičemž jednoprocentní růst nezaměstnanosti vyvolává průměrný pokles inflace o $1,619 \%$. Záporný sklon odhadnuté regrese je shodný s omezením kladeným na parametr $\beta_{2}$, ale hodnota koeficientu determinace je relativně malá $66 \%$ (viz obr. 1), a to i přes vysoký počet pozorování. Navíc z této hodnoty lze usoudit, že míru inflace ovlivňují kromě míry nezaměstnanosti i další proměnné. Tato nízká vysvětlovací schopnost odhadnuté lineární regrese může být také způsobena nevhodně zvoleným typem modelu. 


\section{Obr. č. 1: Výsledky odhadu parametrů původní Phillipsovy křivky} (výstup z programu MS Excel)

\begin{tabular}{||l|c||}
\hline \multicolumn{2}{|c|}{ Regresní statistika } \\
\hline Násobné R & 0,812 \\
\hline Hodnota spolehlivosti R & 0,660 \\
\hline Nastavená hodnota spolehlivosti R & 0,657 \\
\hline Chyba stř. hodnoty & 1,946 \\
\hline Pozorování & 120 \\
\hline
\end{tabular}

\begin{tabular}{|l|c|c|c||}
\hline & Koeficienty & t stat & \multicolumn{1}{c|}{ Hodnota P } \\
\hline \hline Hranice & 17,17335533 & 19,17904935 & $4,5972 E-38$ \\
\hline Soubor X 1 & $-1,619345713$ & $-15,11958907$ & $2,21112 E-29$ \\
\hline
\end{tabular}

\begin{tabular}{||l|c|c|c|c|c||}
\hline \hline \multicolumn{7}{|l|}{ ANOVA } & \multicolumn{1}{|c||}{ SS } & MS & F & Významnost F \\
\hline \hline Regrese & 1 & 866,102332 & 866,102332 & 228,601974 & $2,21112 E-29$ \\
\hline Rezidua & 118 & 447,065585 & 3,7886914 & & \\
\hline Celkem & 119 & 1313,16792 & & & \\
\hline \hline
\end{tabular}

V obrázku 1 je uvedeno několik charakteristik, které popisují kvalitu zvoleného modelu. Mezi nejdůležitější patří statistická významnost F-testu. Jeho p-hodnota $\left(2,2 \cdot 10^{-29}\right)$ musí být menší než hladina významnosti $\alpha=0,05$, abych mohla daný model s $95 \%$ spolehlivostí model přijmout. Koeficient determinace (66\%) posuzuje jeho kvalitu, tj. do jaké míry tento regresní model vystihuje závislost celkové inflace na nezaměstnanosti. P-hodnoty t-testů jednotlivých regresních parametrů $\left(4,6 \cdot 10^{-38}\right.$ a $\left.2,2 \cdot 10^{-29}\right)$ mi ukazují, zda je mohu oba považovat za statisticky významné (zvolená hladina významnosti je $\alpha=0,05$ ).

\section{Graf č. 1: Původní model Phillipsovy křivky}

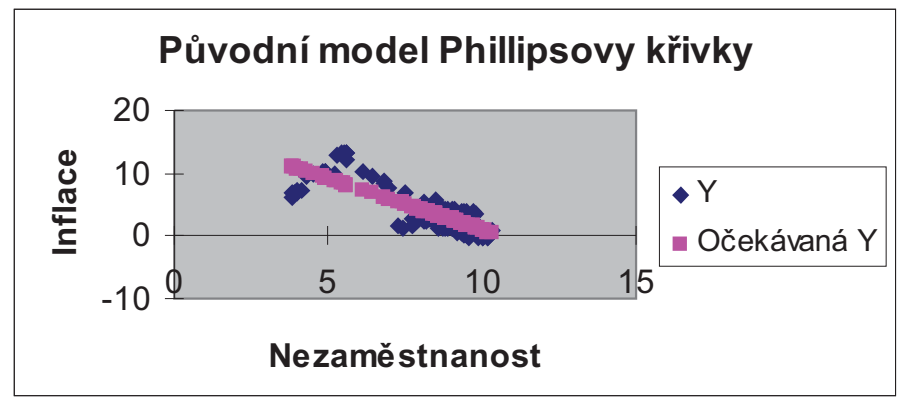

\subsection{Hyperbolický model Phillipsovy křivky}

Další model Phillipsovy křivky, který má tvar hyperboly (viz vztah 1/7), byl odhadnut podobně jako předchozí model. Má tvar

$$
\hat{\pi}_{t}=-3,996+60,855 \cdot U_{t}^{-1}
$$


Vztah (2/2) ukazuje, že s rostoucí mírou nezaměstnanosti klesá inflace stále pomaleji. Odhady parametrů v rovnici splňují podmínky kladené na koeficienty. Hodnota koeficientu determinace je $\mathrm{v}$ tomto př́ípadě nižší než v předchozím lineárním tvaru, činí $53 \%$ (viz obr. 2). Z obrázku 2 dále vyplývá, že p-hodnota pro F-test regresního modelu $\left(4,3 \cdot 10^{-21}\right)$ i p-hodnoty pro t-testy obou parametrů $\left(1,5 \cdot 10^{-7}\right.$ a $\left.4,3 \cdot 10^{-21}\right)$ jsou menší než zvolená $5 \%$ hladina významnosti, takže model i výsledné koeficienty jsou statisticky významné.

Obr. č. 2: Výsledky odhadu parametrů hyperbolického modelu Phillipsovy křivky (výstup z programu MS Excel)

\begin{tabular}{||l|c||}
\hline \multicolumn{2}{|c|}{ Regresní statistika } \\
\hline \hline Násobné R & 0,72825551 \\
\hline Hodnota spolehlivosti R & 0,53035608 \\
\hline Nastavená hodnota spolehlivosti R & 0,52637605 \\
\hline Chyba stř. hodnoty & 2,28614345 \\
\hline Pozorování & 120 \\
\hline
\end{tabular}

\begin{tabular}{|l|c|c|c||}
\hline & Koeficienty & t stat & Hodnota P \\
\hline Hranice & $-3,996073075$ & $-5,585035298$ & $1,52092 E-07$ \\
\hline Soubor X 1 & 60,85523122 & 11,54357772 & $4,30526 E-21$ \\
\hline
\end{tabular}

\begin{tabular}{||l|c|c|c|c|c||}
\hline \hline ANOVA & \multicolumn{5}{|c||}{} \\
\hline & Rozdíl & SS & MS & F & Významnost F \\
\hline Regrese & 1 & 696,446594 & 696,446594 & 133,254186 & $4,30526 E-21$ \\
\hline Rezidua & 118 & 616,721323 & 5,22645189 & & \\
\hline Celkem & 119 & 1313,16792 & & & \\
\hline \hline
\end{tabular}

Graf č. 2: Phillipsova křivka ve tvaru hyperboly

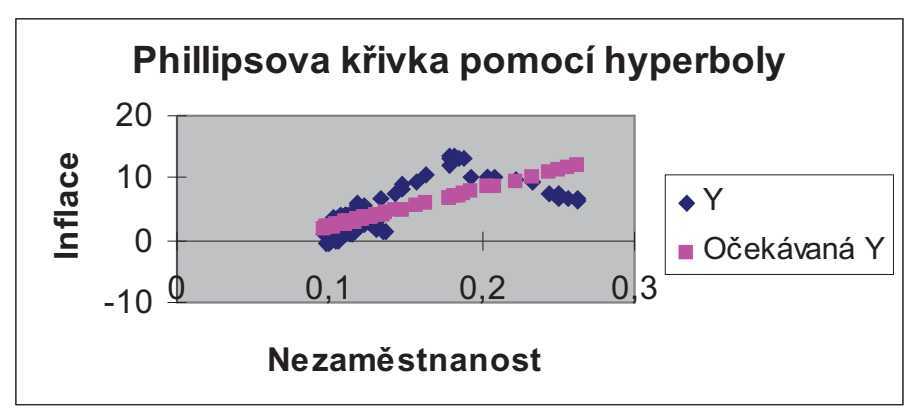

\subsection{Neoklasický model Phillipsovy křivky}

Neoklasická podoba Phillipsovy křivky má tvar daný vztahem (1/8). Původní podoba Phillipsovy křivky je zde rozšířena o očekávanou míru inflace $\pi_{t}^{e}$. Z použitých dat jsem získala model ve tvaru

$$
\hat{\pi}=0,947-0,084 \cdot U_{t}+0,947 \pi_{t}^{e}
$$


V tomto modelu jsem je vysoký koeficient vícenásobné determinace v hodnotě $96 \%$ (po přepočtení na jeden stupeň volnosti je to 95,9\%), což je mnohem více než v předchozích dvou případech. Znamená to, že proměnné nezaměstnanost a očekávaná inflace vysvětlují 96\% celkového rozptylu skutečné míry inflace v období leden 1997 až prosinec 2006. Na druhé straně došlo k tomu, že model sám o sobě je statisticky významný (p-hodnota je $1,5 \cdot 10^{-82}$ ), ale první dva regresní koeficienty $\beta_{1}$ a $\beta_{2}$ jsou statisticky nevýznamné (příslušné p-hodnoty jsou 0,13356 a 0,18539) (viz obr. 4).

Obr. č. 3: Výsledky odhadu parametrů neoklasické podoby Phillipsovy křivky (výstup z programu MS Excel)

\begin{tabular}{||l|c||}
\hline \multicolumn{2}{|c||}{ Regresní statistika } \\
\hline \hline Násobné R & 0,97983512 \\
\hline Hodnota spolehlivosti R & 0,96007686 \\
\hline Nastavená hodnota spolehlivosti R & 0,95939441 \\
\hline Chyba stř. hodnoty & 0,66939053 \\
\hline Pozorování & 120 \\
\hline
\end{tabular}

\begin{tabular}{||l|c|r|r||}
\hline & Koeficienty & t stat & Hodnota P \\
\hline \hline Hranice & 0,947938896 & 1,510686471 & 0,13356447 \\
\hline Soubor X 1 & $-0,084581161$ & $-1,332168719$ & 0,185393806 \\
\hline Soubor X 2 & 0,947050148 & 29,67706019 & $2,7554 E-56$ \\
\hline \hline
\end{tabular}

\begin{tabular}{|l|r|r|r|r|r||}
\hline ANOVA & & & & & \\
\hline & Rozdíl & \multicolumn{1}{c|}{ SS } & MS & F & Významnost F \\
\hline \hline Regrese & 2 & 1260,74213 & 630,371063 & 1406,81551 & $1,48473 E-82$ \\
\hline Rezidua & 117 & 52,42579 & 0,44808368 & & \\
\hline Celkem & 119 & 1313,16792 & & & \\
\hline
\end{tabular}

Graf č. 3: Neoklasická podoba Phillipsovy křivky

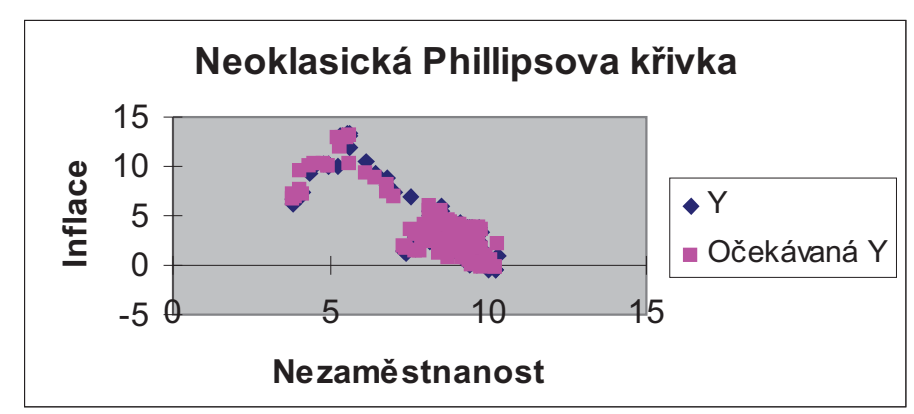




\section{4 Čtvrtletní model Phillipsovy křivky upravený pro českou ekonomiku}

Čtvrtletní model krátkodobé Phillipsovy křivky rozšířrený o očekávanou míru inflace, který byl upraven pro českou ekonomiku Huškem a Moravovou 2001 viz [3], je vyjádřen vztahem (1/9). Po dosazení dat jsem získala model

$$
\hat{\pi}=5,910-0,442 \cdot U_{t}+0,903\left(\pi_{t}^{e}\right)^{2} .
$$

Vztah (2/4) říká, že při konstantní nezaměstnanosti v ČR v daném období vyvolá zvýšení očekávané míry inflace o jedno procento růst skutečné inflace o $0,9 \%$, ale také zvýšení o 5,91\%, takže v konečném důsledku se zvýší o 6,81\%.

Pro další práci si zvolím tento model, i když nemá nejvyšší vypovídací hodnotu (o 3,1\% nižší než předchozí model - viz obr. 4), ale je statisticky významný (s p-hodnotou $6,0 \cdot 10^{-22}$ ), včetně výsledných koeficientů (s p-hodnotami $3,5 \cdot 10^{-5}, 0,0028$ a 5,2 $\cdot 10^{-13}$.

Obr. č. 4: Výsledky odhadu parametrů upraveného čtvrtletního modelu Phillipsovy křivky (výstup z programu MS Excel)

\begin{tabular}{||l|c|}
\hline \multicolumn{2}{|c|}{ Regresní statistika } \\
\hline Násobné R & 0,96369824 \\
\hline Hodnota spolehlivosti R & 0,92871431 \\
\hline Nastavená hodnota spolehlivosti R & 0,92486103 \\
\hline Chyba stř. hodnoty & 0,90312564 \\
\hline Pozorování & 40 \\
\hline
\end{tabular}

\begin{tabular}{|l|c|c|c||}
\hline & Koeficienty & t stat & Hodnota P \\
\hline \hline Hranice & 5,910916417 & 4,706347866 & $3,48173 E-05$ \\
\hline Soubor X 1 & $-0,441600705$ & $-3,202807418$ & 0,002797562 \\
\hline Soubor X 2 & 0,061478413 & 10,81761519 & $5,15966 E-13$ \\
\hline
\end{tabular}

\begin{tabular}{||l|c|c|c|c|c||}
\hline ANOVA & Rozdíl & SS & MS & F & Významnost F \\
\hline \hline Regrese & 2 & 393,167693 & 196,583847 & 241,019115 & $6,03315 E-22$ \\
\hline Rezidua & 37 & 30,1785289 & 0,81563592 & & \\
\hline Celkem & 39 & 423,346222 & & & \\
\hline \hline
\end{tabular}




\section{Graf č. 4: Upravený čtvrtletní model Phillipsovy křivky}

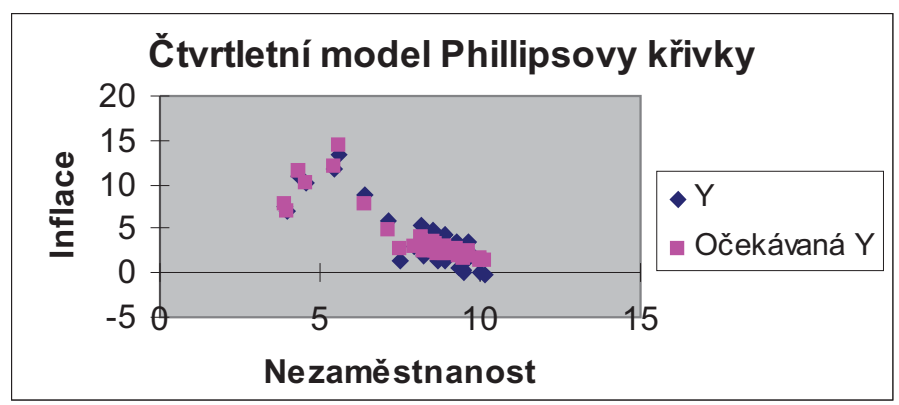

\section{Závěr}

Z výsledků provedené analýzy vyplývá, že ze všech testovaných modelů nejlépe vystihuje závislost nezaměstnanosti na vývoji inflace v České republice v období 1997-2006 poslední model, tj. čtvrtletní model krátkodobé Phillipsovy křivky rozšířený o očekávanou míru inflace, který byl upraven speciálně pro českou ekonomiku autory Huškem a Moravcovou. Ačkoliv neoklasický model Phillipsovy křivky vysvětloval závislost z 96\% a čtvrtletní model pouze z 93\%, ukázalo se, že u neoklasické podoby je vývoj inflace závislý pouze na očekávané inflaci. Abstrahuje se od vlivu nezaměstnanosti, takže závisí pouze na očekáváních. Kdežto ve čtvrtletním modelu má je tento vývoj ovlivněn jak nezaměstnaností, tak kvadrátem očekávané inflace. Je vidět, že i v tomto modelu má očekávaná hodnota výrazný vliv na vývoj skutečné inflace. Přitom očekávanou inflaci lze jen minimálně ovlivnit ekonomickými nástroji. To znamená, že vývoj nezaměstnanosti má oproti vývoji očekávané inflace mnohem menší vliv na vývoj inflace skutečné.

\section{Literatura}

[1] BARTOŠOVÁ, J.: Modelování v ekonomii. Elektronická forma skript, FM VŠE J. Hradec, 2006

[2] HUŠEK R., PELIKÁN J. :Aplikovaná ekonometrie. Professional Publishing, 2003, ISBN 80-86419-29-0

[3] Český statistický úřad. http://www.czso.cz/csu/redakce.nsf/i/mira_inflace

[4] Integrovaný portál MPSV: Zaměstnanost. http://portal.mpsv.cz/sz/stat/nz/mes

[5] Liberální institut. http://www.libinst.cz/clanky.php?id=680 